\title{
Soil Arsenic in Miami-Dade County ${ }^{1}$
}

\section{Yuncong Li, Ashley Smyth, Jonathan Crane, Christopher Teaf, and Guangliang Liu ${ }^{2}$}

This factsheet provides information about soil arsenic (As) in Miami-Dade County, Florida, including basics, background concentrations, cleanup guidelines of soil As, and bioavailability of soil As related to plant and human health. It was written for Extension agents, environmental professionals, representatives of governmental regulatory agencies, land managers, researchers, landowners, and anyone concerned about soil arsenic in Miami-Dade County.

\section{Basics of Arsenic}

Arsenic (As) is a silver-gray or white solid element with almost no odor or taste. It is often referred to as a metalloid, nonmetal, or semimetal because its physical and chemical properties are intermediate between a metal and a nonmetal. It is rarely found in the elemental form, but rather usually combined with oxygen, chlorine, sulfur, or other elements to form inorganic arsenic compounds, such as trivalent compounds (e.g., arsenic trioxide, sodium arsenite, and arsenic trichloride) and pentavalent compounds (e.g., arsenic pentoxide, lead arsenate, and calcium arsenate). Arsenic also can be present in an organic form as a combination with carbon and hydrogen, such as arsanilic acid (used for veterinary feed additives) and methylarsonic acid (used for pesticides). Although As can exist in a variety of forms in the environment, total As content is usually used to assess toxicity and bioavailability, even though it may not be a perfect indicator of those attributes.

\section{Arsenic in Soil Natural Arsenic in Soil}

Arsenic is a naturally occurring element widely distributed (20th most common) in the Earth's crust. Abundance of arsenic typically is in the range of $1.5-3.4 \mathrm{mg} / \mathrm{kg}$ worldwide, with higher levels in geologically specific areas (Smith et al. 1998; Kapp 2014). Arsenic is present in all soils, and arsenic content in soils depends on the geological history during soil formation. The background arsenic concentrations of natural undisturbed soils are in the range of $0.1-40 \mathrm{mg} /$ $\mathrm{kg}$, with an average of 5-6 mg/kg (USNRC 1977). There are over 150 arsenic-bearing minerals in soils, such as realgar $\left(\mathrm{As}_{4} \mathrm{~S}_{4}\right)$, pharmacolite $\left[\mathrm{Ca}\left(\mathrm{HAsO}_{4}\right) \cdot 2 \mathrm{H}_{2} \mathrm{O}\right]$, and arsenopyrite (FeAsS). Arsenic concentrations in limestone-based calcareous soils range from 0.1 to $20 \mathrm{mg} / \mathrm{kg}$ with an average of $1.7 \mathrm{mg} / \mathrm{kg}$ (USNRC 1977). Arsenic is released from rocks and soils into the environment due to weathering (e.g., erosion, leaching).

\section{Anthropogenic Arsenic in Soil}

Arsenic is a nonessential trace element for plants, while there is some evidence that the element may have essentiality in humans. It was used to treat a variety of ailments in the 19th and 20th centuries, though it has not been used in that manner for over 50 years (NCBI 2020). The common historical anthropogenic sources of arsenic in soil include wood preservatives (phased out in the early 2000s),

1. This document is SL483, one of a series of the Department of Soil and Water Sciences, UF/IFAS Extension. Original publication date March 2021. Visit the EDIS website at https://edis.ifas.ufl.edu for the currently supported version of this publication.

2. Yuncong Li, professor, soil and water quality; Ashley Smyth, assistant professor, biogeochemistry, Department of Soil and Water Sciences; Jonathan Crane, professor, tropical fruit crop specialist, Horticultural Sciences Department, and associate center director, UF/IFAS Tropical Research and Education Center; Christopher Teaf, director, Toxicology and Human Health Risk Assessment, Institute for Science \& Public Affairs, Florida State University, and president and director of toxicology, Hazardous Substance \& Waste Management Research, Inc. (HSWMR); and Guangliang Liu, research specialist, Department of Chemistry \& Biochemistry, Florida International University; UF/IFAS Extension, Gainesville, FL 32611.

The Institute of Food and Agricultural Sciences (IFAS) is an Equal Opportunity Institution authorized to provide research, educational information and other services

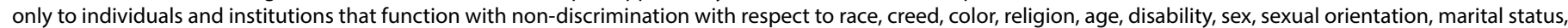

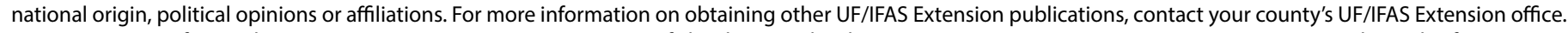
U.S. Department of Agriculture, UF/IFAS Extension Service, University of Florida, IFAS, Florida A \& M University Cooperative Extension Program, and Boards of County Commissioners Cooperating. Nick T. Place, dean for UF/IFAS Extension. 
agricultural use (pesticides), cattle-dipping vats (1906-1962 in Florida), biosolids (Florida regulation of biosolids was adopted in 1984), solid wastes from industrial processes (e.g., mining, smelting, batteries), and emissions from incineration and fuel combustion. Even though there is no literature to confirm, arsenical pesticides were probably used on various crops in Miami-Dade County in the early 20th century, and the use of inorganic arsenical pesticides (e.g., lead arsenate) was banned in 1988 nationwide. Organic arsenical pesticides (e.g., monosodium methanearsonate [MSMA]) were phased out of use except on cotton plants in Florida since 2013 (US EPA 2019). Cotton is not grown in Miami-Dade County. Commercial products containing As are no longer produced in the United States, and all As products used in the United States are imported from other countries.

\section{Arsenic in Florida Soils}

Background concentrations of As in Florida soils were determined based on 448 soil samples collected by the USDA-Natural Resource Conservation Service (NRCS) between the 1960s and 1990s for Florida soil survey, originating from 51 of 67 counties and $80 \%$ of the total land area of Florida (Chen et al. 1999). Surface soils from Miami-Dade County had the highest average of As ( $>7.02$ $\mathrm{mg} / \mathrm{kg}$ ), and soils from Brevard County had the second highest average As (3.7-7.02 mg/kg) (Figure 1). Both counties are located on the Atlantic coast; rocks and soils formed in the marine environment of those counties and others are often enriched with As compared to those from nonmarine origins (Valette-Silver et al. 1999; Smedley and Kinniburgh 2002). This is because there is As in seawater, and As tends to accumulate in sediments once in contact with seawater. However, it is difficult to explain why other coastal counties do not have elevated As levels similar to those in Miami-Dade.

A study conducted recently by Scott-Richardson et al. (2019) evaluated eight As sources, including background surface soil As, background groundwater As, phosphate mining, cattle-dipping vats, and pesticide use (e.g., monosodium methanearsonate, disodium methanearsonate, lead arsenate) in 67 counties in Florida, and concluded that the southwestern and southeastern counties near Miami had the highest arsenic distributions from natural sources (Figure 2).

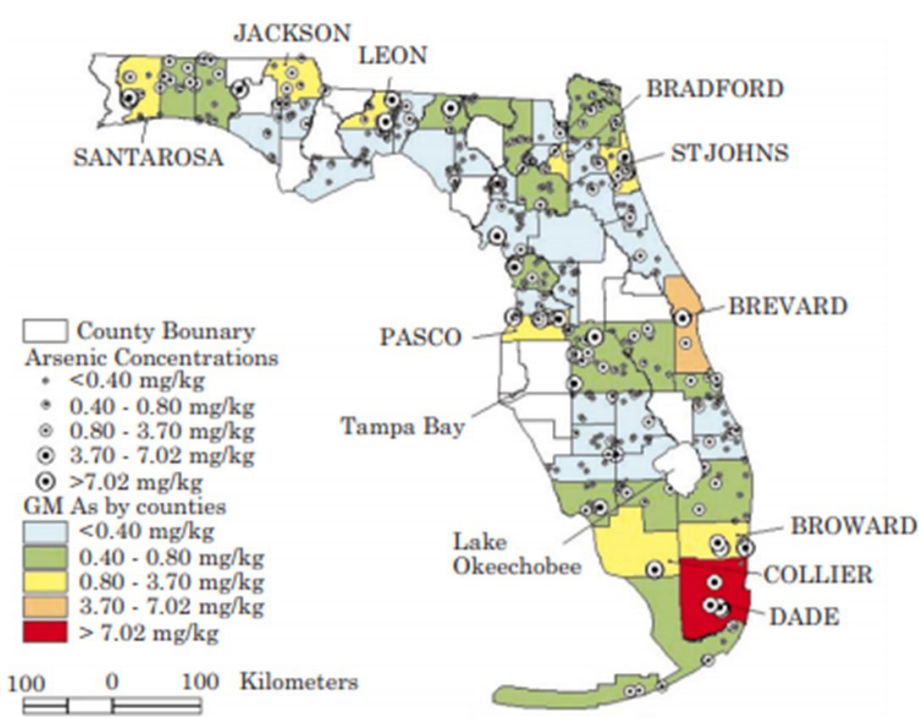

Figure 1. Map of arsenic concentrations in Florida surface soils. The red color was indicative of the highest As values, not elevated human risk. Credits: Chen et al. (2001)

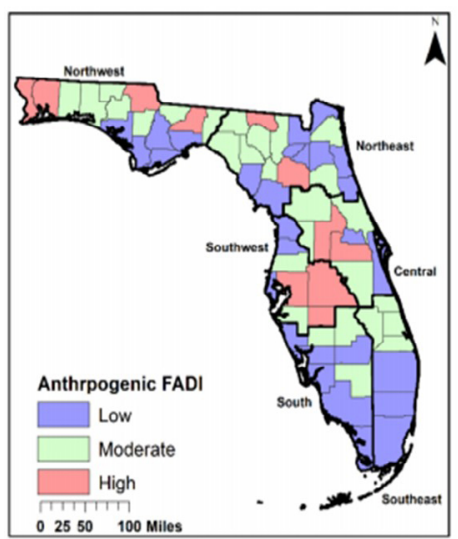

(a)

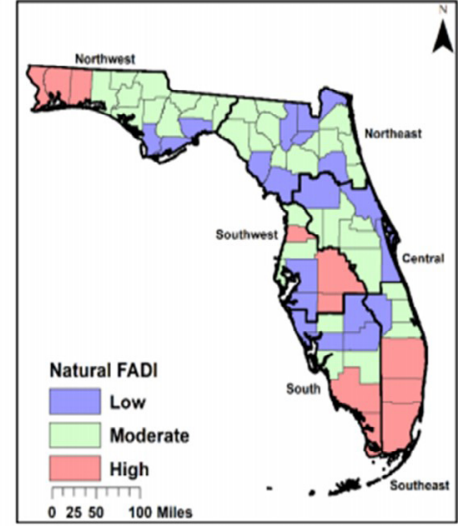

(b)
Figure 2. Florida Arsenic Distribution Indices (FADIs): (a) anthropogenic source and (b) natural source. The colors represent levels of contribution of anthropogenic sources or natural sources for soil As. Credits: Scott-Richardson et al. (2019)

\section{Arsenic in Undisturbed Soils in Miami-Dade County}

All soils in Miami-Dade County are limestone-based calcareous soils overlaying natural limestone formations. Arsenic concentrations ranged from $3.3-13 \mathrm{mg} / \mathrm{kg}$ for bedrocks collected from the south Everglades (Chen et al. 2000). Samples collected from marl (sedimentary soil parent material containing predominantly calcium carbonate) soils that overlie these rocks in the Everglades had 0.6-29.8 $\mathrm{mg} / \mathrm{kg}$ As, with $4 \mathrm{mg} / \mathrm{kg}$ as the average concentration of As in surface marl soils (0-6 inches) (Table 1). The study of As background concentrations by the University of Florida showed that the Everglades region, including Miami-Dade County in south Florida, had the highest As concentrations among surface soils in Florida, which was associated with 
the heavy occurrence of peat, limestone, and shelly marl (Chen et al. 2001).

The Miami-Dade County Division of Environmental Resources Management (DERM) conducted the natural background study for Miami-Dade County soils in 2001 and collected 38 soil samples from unimpacted areas, such as parks in the county. The study results showed the range of As concentrations in these soils was $0.1-3.89 \mathrm{mg} / \mathrm{kg}$, with an average (MVUE [Minimum Variance Unbiased Estimate of the mean]) of $1.2 \mathrm{mg} / \mathrm{kg}$, which was referenced as the natural background concentration for Miami-Dade County soils by DERM. In the same study, DERM reported that 8 samples of rock mining quarries and 22 samples of dragline materials from Miami-Dade County had As below the reported detection limit $(0.2 \mathrm{mg} / \mathrm{kg})$ (DERM 2002). Relatively low As concentrations in both soils and rocks from this study may be due to sampling locations of soils and deep depths of rock cores sampled, even though the report of that study did not provide geographic references or addresses for the sampling locations. The natural background of soil As concentrations for the barrier islands of Miami-Dade County were also studied by DERM (2004) based on soil samples collected from 27 locations along Miami Beach and the spoil island, and they reported an average (MVUE) of $5.2 \mathrm{mg} / \mathrm{kg}$ with a range from below detection limit to $15.1 \mathrm{mg} / \mathrm{kg}$ As (DERM 2004). Arsenic concentrations in uncontaminated marine and estuarine sediment range between 5-15 mg/kg (Neff 1997).

\section{Arsenic in Disturbed Soil in Miami- Dade County}

DERM conducted an anthropogenic background study of Miami-Dade County soils between 2011 and 2014 and collected samples for upper surface soil (0-6 inches) and lower surface soil (6-24 inches) from 160 locations throughout the urban corridor (within the 2015 Urban Development Boundary [UDB]) of the county (DERM 2014). The study results showed the MVUE values of As in surface soils (0 to 6 inch depth) were $4.2 \mathrm{mg} / \mathrm{kg}$ countywide, $3.5 \mathrm{mg} / \mathrm{kg}$ north of SW 88 Street, and $7 \mathrm{mg} / \mathrm{kg}$ south of SW 88 Street, and the MVUE values for subsoils ( 6 to 24 inch depth) were 2.9 $\mathrm{mg} / \mathrm{kg}$ countywide, $2.1 \mathrm{mg} / \mathrm{kg}$ north of SW 88 Street, and $5 \mathrm{mg} / \mathrm{kg}$ south of SW 88 Street (Figure 3). The above study did not include current farmlands, and most sampling sites probably were never affected by noticeable anthropogenic sources or never recorded as using arsenic-containing pesticides. Therefore, these values may be interpreted as the natural background of soil As in the county.
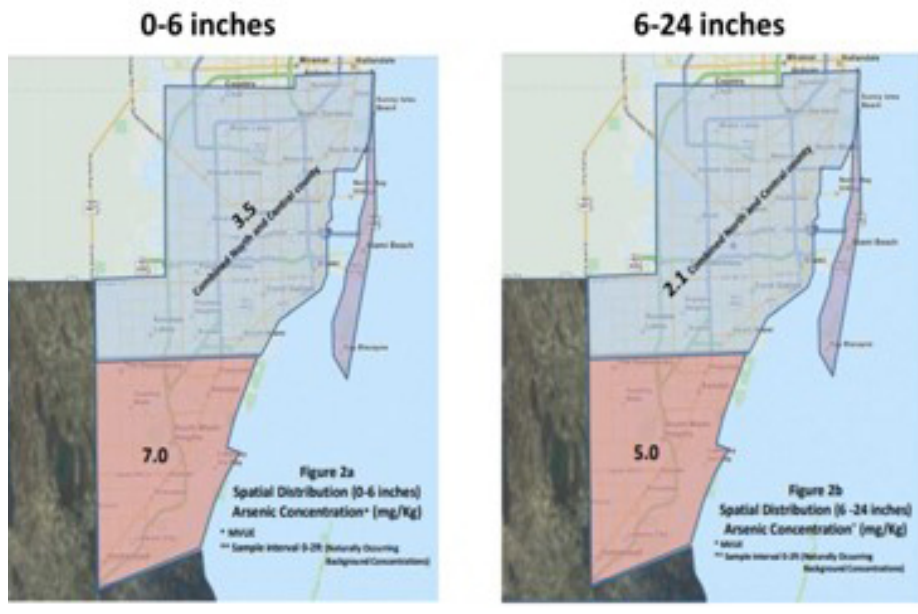

Figure 3. Spatial distribution of arsenic concentrations in surface soils (0-6 inches) and subsurface soils (6-24 inches).

Credits: DERM (2014)

By comparing seven marl soil samples from farmland and eleven marl soil samples from natural land collected by USDA-NRCS for the Miami-Dade County soil survey during the 1980s, Chen et al. (2000) reported that there was no significant difference of arsenic concentrations between disturbed (rock-plowed [the process to crush the oolitic limestone bedrock with a scarifying plow front-mounted on a large bulldozer] farmland) and undisturbed background soils (from the Everglades). Additionally, Chen et al. (2000) observed that high concentrations of As in both disturbed and undisturbed marl soils may not all originate from anthropogenic sources and may attribute to elemental accumulation during formation of calcite.

\section{Arsenic Bioavailability to Plants and Leachability in Calcareous Soils}

There is no report for As detected in fruits and vegetables produced in Miami-Dade County, and bioavailability of As is very low in local calcareous soils, which have unique characteristics (e.g., high $\mathrm{pH}$ and high concentrations of calcium, magnesium, iron, aluminum, and other cations). These characteristics favor the formation/precipitation of arsenate solid species (e.g., calcium arsenates, magnesium arsenates, and iron arsenates). This way, As would be retained in solid matrices in soil and remain unavailable for uptake by plants. For the same reason, leachability of As in these soils should also be very low. These soils also have relatively high contents of clay minerals and organic matter, which can adsorb As and prevent leaching of As from soils. Predominant minerals in soils from Miami-Dade County are calcite in marl soils and kaolinite, montmorillonite, and hydroxides of iron, calcium and aluminum in Krome soils (Noble et al. 1996; Li 2001). After comparing As in 
soils collected from Gainesville and Miami, Chirenje et al. (2003) stated that the high capability of As retention by soils from Miami was due to higher silt and clay contents and the presence of significant amounts of calcium carbonate. It should be acknowledged that As is one of the most frequently encountered inorganic contaminants of concern for groundwater contamination in Miami-Dade County, and high As concentrations were detected in many sites in the county (DERM, personal communication).

\section{Arsenic Bioavailability and Potential Human Health Risk}

According to the (ATSDR), minimal risk level (MRL) for acute oral ingestion of As is $0.005 \mathrm{mg} / \mathrm{kg} /$ day (ATSDR 2020). The health risk strongly depends on bioavailable As from incidental ingestion of soil. Bioavailability of soil As refers to how much As is absorbed into the body following exposure (e.g., ingestion) to As-containing soil.

A soil As bioavailability study was conducted by Roberts et al. (2002) with surface soils (0-6 inches) collected by the Florida Department of Environmental Protection (FDEP) from previously identified As-contaminated areas (electrical substations [312 mg As/kg]; a cattle dip site [189 $\mathrm{mg} \mathrm{As} / \mathrm{kg}$ ]; a wood treatment site [101 mg As/kg]; and two pesticide loading sites [329-743 mg As/kg]). Based on that bioavailability study, the Florida Soil Cleanup Target Level (SCTL) for As was adjusted in 2005 from $0.8 \mathrm{mg}$ As/ $\mathrm{kg}$ to $2.1 \mathrm{mg} \mathrm{As} / \mathrm{kg}$ for residential use and from $3.7 \mathrm{mg}$ As/kg to $12 \mathrm{mg} \mathrm{As} / \mathrm{kg}$ for commercial and industrial use (Center for Environmental \& Human Toxicology 2005). The Code of Miami-Dade County (updated on September 24, 2020) adopted Florida SCTLs, including $2.1 \mathrm{mg} \mathrm{As/kg}$ for residential sites.

While As is a known human carcinogen at sufficient levels in water, credible reports of health effects associated with soil arsenic at low concentrations have not been identified. A variety of soil cleanup guidelines are available from state, federal, and international agencies and vary across about a thousandfold range ( 0.039 to $40 \mathrm{mg} / \mathrm{kg}$ ) in the United States alone, with no consensus regarding a universal recommendation (Table 3).

As discussed in the previous section, calcareous soils in Miami-Dade County have high contents of clay, oxides of iron and aluminum, and calcium carbonate, and the binding of As to these minerals is expected to be very strong and to dramatically reduce bioavailability of As in soils that may accidentally enter a human body. As reported, iron binding of As resulted in much less bioaccessibility inside the human body (Zhong et al. 2017), and calcareous soils in Miami-Dade County have about 50-200 times more iron than soils in other parts of Florida.

\section{Summary}

Natural geochemical and marine depositional processes are possible causes for high levels of As in soils and bedrock in Miami-Dade County. Due to unique physical, chemical, mineralogical, and biological characteristics of calcareous soils, bioavailability and acute toxicity of As in these soils to plants and humans should be very low compared to soils outside the county. Because soils in this county have high levels of naturally occurring arsenic, it is not necessary to clean up to conditions that are less than natural background levels based on Miami-Dade County's Code. However, further studies of bioavailability of As in these specific soils to plants and humans may be conducted to determine whether bioavailability is sufficiently low that a risk-based arsenic cleanup goal above a Miami-Dade-specific background might be warranted. An additional study may be conducted as well to determine naturally occurring background concentrations of As in the south Dade agricultural area of the county.

\section{Acknowledgments}

The authors sincerely thank the Miami-Dade County Agricultural Practices Advisory Board, Sam Accursio and other growers for their inputs, Drs. Leah Stuchal and Steve Roberts, University of Florida's Center for Environmental \& Human Toxicology (CEHT), and professional staff at the Miami-Dade County Division of Environmental Resources Management (DERM) for their valuable comments and suggestions.

\section{References}

ATSDR (Agency for Toxic Substances and Disease Registry). 2020. "Minimal Risk Levels (MRLs) List." https:// wwwn.cdc.gov/TSP/MRLS/mrlsListing.aspx

Center for Environmental \& Human Toxicology. 2005. Technical Report: Development of Cleanup Target Levels (CTLs) for Chapter 62-777, F.A.C. https://floridadep.gov/ sites/default/files/1-TechnicalReport2FinalFeb2005_0.pdf

Chen, M., L. Q. Ma, and W. G. Harris. 1999. "Baseline Concentrations of 15 Trace Elements in Florida Surface Soils." J. Environ. Qual. 28:1173-1181. 
Chen, M., L. Q. Ma, and W. G. Harris. 2001. “Arsenic Background Concentrations in Florida, U.S.A. Surface Soils: Determination and Interpretation." Environ. Forensics $2: 117-126$.

Chen, M., L. Q. Ma, and Y. C. Li. 2000. "Concentrations of $\mathrm{P}, \mathrm{K}, \mathrm{Al}, \mathrm{Fe}, \mathrm{Mn}, \mathrm{Cu}, \mathrm{Zn}$, and As in Marl Soils from South Florida." Proc. Soil Crop Sci. Soc. Fla. 59:124-129.

DERM (Division of Environmental Resource Management), Regulation and Economic Resources, Miami-Dade County. 2000. "Natural Background Concentrations in Soil for Miami-Dade County." https://www.miamidade.gov/ environment/library/memos/soil-study.pdf

DERM (Division of Environmental Resource Management), Regulation and Economic Resources, Miami-Dade County. 2004. "Natural Background Soil Concentrations for the Barrier Islands of Miami-Dade County." https://www. miamidade.gov/environment/library/memos/islands-soilstudy.pdf

DERM (Division of Environmental Resource Management), Regulation and Economic Resources, Miami-Dade County. 2014. "Miami-Dade County Anthropogenic Background Study." https://www.miamidade.gov/environment/ library/reports/2014-anthropogenic-background-study.pdf

Duan, Z. 2012. "The Distribution of Toxic and Essential Metals in the Florida Everglades." Master's thesis, Florida International University. https://pdfs.semanticscholar.org/2 14d/2ca52d2c4c57ce495266e8ba463cda9a21b0.pdf

Kapp, R. W. 2014. “Arsenic." In Encyclopedia of Toxicology, 3rd ed., edited by P. Wexler, 308-312. New York: Academic Press.

Li, Y. C. 2001. "Calcareous Soils in Miami-Dade County." EDIS 2001 (4). https://edis.ifas.ufl.edu/tr004.

NCBI (National Center for Biotechnology Information). 2020. "PubChem Compound Summary for CID 5359596, Arsenic.” Retrieved November 21, 2020. https://pubchem. ncbi.nlm.nih.gov/compound/Arsenic.

Neff, J. M. 1997. "Ecotoxicology of Arsenic in the Marine Environment." Environmental Toxicology and Chemistry 16:917-927.

Noble, C. V., R. W. Drew, and J. D. Slabaugh. 1996. Soil Survey of Dade County Area, Florida. USDA-NRCS. Washington, D.C.: U.S. Government Printing Office.
Roberts, S. M., W. R. Weimar, J. R. T. Vinson, J. W. Munson, and R. J. Bergeron. 2002. "Measurement of Arsenic Bioavailability in Soil Using a Primate Model." Toxicological Sciences 67 (2): 303-310. https://doi.org/10.1093/ toxsci/67.2.303

Scott-Richardson, M., M. O’Hara Ruiz, and R. L. Smith. 2019. "Florida Arsenic Distribution Index: Quantifying the Distribution of Past and Present Arsenic Usage." International Journal of Environmental Research and Public Health 16 (5): 744. https://doi.org/10.3390/ijerph16050744

Smedley, P. L., and D. G. Kinniburgh. 2002. "A Review of the Source, Behaviour and Distribution of Arsenic in Natural Waters." Appl. Geochem. 17:517-568. https://doi. org/10.1016/S0883-2927(02)00018-5

Smith, E., R. Naidu, and A. M. Alston. 1998. "Arsenic in the Soil Environment: A Review.” Adv. Agron. 64:149-195.

Teaf, C. M., D. J. Covert, P. A. Teaf, E. Page, and M. J. Starks. 2010. "Arsenic Cleanup Criteria for Soils in the US and Abroad: Comparing Guidelines and Understanding Inconsistencies." Proceedings of the Annual International Conference on Soils, Sediments, Water and Energy 15:10. https://scholarworks.umass.edu/soilsproceedings/vol15/ iss $1 / 10$

US EPA (Environmental Protection Agency). 2019. "Monosodium Methanearsonate (MSMA), an Organic Arsenical." https://www.epa.gov/ingredients-used-pesticide-products/ monosodium-methanearsonate-msma-organic-arsenical

USNRC (United States National Research Council). 1977. Arsenic: Medical and Biologic Effects of Environmental Pollutants. Washington, D. C.: National Academies Press. https://www.ncbi.nlm.nih.gov/books/NBK231016/

Valette-Silver, N. J., G. F. Riedel, E. Crecelius, H. Windom, R. G. Smith, and S. S. Dolvin. 1999. "Elevated Arsenic Concentrations in Bivalves from the Southeast Coasts of the USA." Marine Environmental Research 48:311-333.

Zhong, S. X., G. C. Yin, R. L. Huang, H. F. He, Z. L. Chen, Q. T. Lin, and W. K. Wang. 2017. "Effect of Different Iron Minerals on Bioaccessibility of Soil Arsenic Using In Vitro Methods." Huan Jing ke Xue 38 (3): 1201-1208. https://doi. org/10.13227/j.hjkx.201608107 
Table 1. Natural arsenic background $(\mathrm{mg} / \mathrm{kg})$ in undisturbed natural surface soils in Miami-Dade County, the Everglades, and Florida.

\begin{tabular}{|c|c|c|c|c|}
\hline Location & Range & Average $^{a}$ & Bedrock & Reference \\
\hline Countywide & $0.1-3.89$ & 1.2 & $<0.2$ & DERM (2000) \\
\hline Barrier Islands & $N D^{b}-15.1$ & 5.2 & & DERM (2004) \\
\hline North Everglades & $0.07-14.9$ & $2.8-3.13^{c}$ & & Duan (2012) \\
\hline South Everglades & $0.6-29.8$ & 4.0 & $3.3-13$ & Chen et al. (2000) \\
\hline Florida statewide & $0.01-38.2$ & 0.4 & & Chen et al. (2001) \\
\hline \multicolumn{5}{|c|}{ 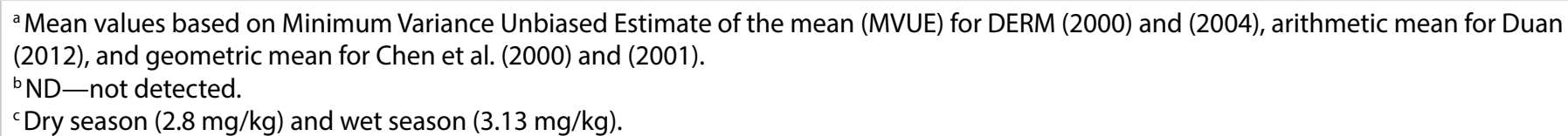 } \\
\hline
\end{tabular}

Table 2. The results of the anthropogenic background study of Miami-Dade County soils between 2011 and 2014 (DERM 2014).

\begin{tabular}{|c|c|c|c|c|}
\hline Sampling site & Depth (inches) ${ }^{a}$ & Range (mg/kg) & Mean (mg/kg) & MVUE (mg/kg) \\
\hline \multirow[t]{2}{*}{ Countywide } & $0-6$ & $0.3-27.3$ & 3.9 & 4.2 \\
\hline & $6-24$ & $0.3-14.5$ & 2.6 & 2.9 \\
\hline \multirow[t]{2}{*}{ North of SW 88 St } & $0-6$ & $0.3-24.8$ & 3.3 & 3.5 \\
\hline & $6-24$ & $0.3-10$ & 1.9 & 2.1 \\
\hline \multirow[t]{2}{*}{ South of SW 88 St } & $0-6$ & $0.3-27.3$ & 5.9 & 7.0 \\
\hline & $6-24$ & $0.3-14.5$ & 4.2 & 5.0 \\
\hline Muck soils & $0-24$ & $0.7-29$ & 4.9 & 4.9 \\
\hline
\end{tabular}

Table 3. Selected cleanup guidelines for US states and other countries for residential/unrestricted use (Teaf et al. 2010)a .

\begin{tabular}{|l|c|l|}
\hline \multicolumn{1}{|c|}{ State/Country } & $\begin{array}{c}\text { Guideline } \\
\text { ( } \mathbf{m g} / \mathbf{k g})\end{array}$ & \\
\hline California & 0.07 & Cancer $\left(10^{-6}\right.$ risk level), 4\% dermal absorption assumption, CalOEHHA Slope Factors \\
\hline Maine & 1.4 & Cancer $\left(10^{-5}\right.$ risk level), CalOEHHA Slope Factors \\
\hline Florida & 2.1 & Cancer $\left(10^{-6}\right.$ risk level), 33\% oral bioavailability, state-specific exposure assumptions \\
\hline Ohio & 6.7 & Cancer $\left(10^{-5}\right.$ risk level), 3\% dermal absorption assumption \\
\hline Texas & 24 & Noncancer (lower than cancer endpoint at $10^{-4}$ risk; $\left.34 \mathrm{mg} / \mathrm{kg}\right)$ \\
\hline Canada & 12 & Soil Quality Guideline: lower of the human health SQG or eco SQG \\
\hline Australia & 100 & $\begin{array}{l}\text { Health-based Investigation Level based on protection of a 2.5-year-old child exposed to 100 mg } \\
\text { soil/day via oral, dermal, and inhalation routes }\end{array}$ \\
\hline a Out of 34 state cleanup criteria for arsenic listed in Teaf et al. (2010), 17 states (50\%) have risk-based criteria 2.1 mg/kg or lower, while an \\
additional 13 states (38\%) use natural background for their criteria, which may be greater than risk-based limits.
\end{tabular}

